\author{
D.A. Zinchenko, A.V. Akimov, M.V. Babii \\ Kherson State Maritime Academy, Ukraine \\ (E-mail: zinchenko010@gmail.com)
}

\title{
The usage of the method of mathematical statistics in the process of optimization of the content of antifriction composite materials
}

\begin{abstract}
The optimum content of microtalc (dispersion $\mathrm{d}=7 \ldots 10 \mu \mathrm{m}$ ) and silver carbonate (dispersion $\mathrm{d}=0,5 \mu \mathrm{m}$ ) fillers in polymeric materials was determined by the method of mathematical statistics to form an adhesive and functional layers of protective coatings. The mathematical models of physicomechanical and thermophysical characteristics of composites were obtained by the method of statistical processing of the results of the investigation materials.
\end{abstract}

Keywords: composite, mathematical statistics, modulus of elasticity, destruction, optimization.

\section{Introduction}

\section{Statement of the problem}

The formation of constructional materials, including polymer ones, with the necessary complex of improved properties is an important problem for today [1-12]. This problem is solved by selecting a range of fillers content in materials, which is achieved using the method of mathematical statistics. Experimental studies related to the optimization of the composition of protective coatings are, as a rule, multifactorial (optimization of composites properties and fillers content). Methods of mathematical statistics allow to adequately assess the content of several fillers of different dispersion, taking into account technological factors, a complex of physicomechanical, thermophysical properties and reliability indicators [13-19].

Analysis of recent researches and publications

The input of fillers of various nature and dispersion into the binder is one of the methods for improving the properties of composite materials (CM) based on an epoxy matrix. Previously, we investigated the influence of fillers of different nature and dispersion on the physic-mechanical and thermophysical properties of CM [20-23]. The optimum content of microdispersed $(7 \ldots 10 \mu \mathrm{m})$ and nanodispersed $(100 \ldots .500 \mu \mathrm{m})$ fillers particles of various nature was established to form coatings of different functional purpose with increased exploitation characteristics.

The results of the experimental studies were statistically processed using the Statgraphics application package to predict the properties and optimize the content of each filler in the PCM.

The purpose of the work is to determine the most optimal mass part of the filler, using multicriteria selection methods for each type of filler.

\section{Experimental results and their discussion}

During the experiment, the influence of two factors (the content of microtalc (MT) and silver carbonate (SC)) on physicomechanical (modulus of elasticity under bending, destructive bending stresses) and thermophysical (heat resistance (by Martens), temperature of the start of the destruction process) properties of PCM were studied.

Output data for statistical processing of the research results of PCM 2, consisting of the epoxy diane resin ED-20 grade $(q=100 \mathrm{wt} \%)$, hardened by polyethylene polyamine $(q=10 \mathrm{wt} \%)$ and filled with particles of MT and SC, are given in Table 1. 
Output data for statistical processing of the research results of PCM properties

\begin{tabular}{|l|c|c|}
\hline \multirow{2}{*}{ The level of variation } & \multicolumn{2}{|c|}{ Variable factors } \\
\cline { 2 - 3 } & $\begin{array}{c}\text { Microtalc content, } \\
q_{1}, \text { wt } \%\end{array}$ & $\begin{array}{c}\text { Silver carbonate content, } \\
q_{2}, \text { wt \% }\end{array}$ \\
\hline Upper & 80 & 0,7 \\
\hline Lower & 60 & 0,3 \\
\hline
\end{tabular}

Output data and results of the implementation of the mathematical model in accordance with the study of PCM properties are given in Table 2.

Table 2

\section{Output data and results of the implementation of the mathematical model in the experimental research of PCM properties}

\begin{tabular}{|c|c|c|c|c|c|c|}
\hline \multirow{2}{*}{ Number of experiment } & \multicolumn{2}{|c|}{ Factors } & \multicolumn{4}{c|}{ Response } \\
\cline { 2 - 7 } & $q_{1}(A)$ & $q_{2}(B)$ & $E$ & $\sigma_{b}$ & $T$ & $T_{0}$ \\
\cline { 2 - 7 } & wt \% & wt \% & GPa & MPa & K & K \\
\hline 1 & 70 & 0,78 & 7,2 & 32,8 & 376 & 624 \\
\hline 2 & 84 & 0,5 & 6,8 & 22,6 & 370 & 618 \\
\hline 3 & 55 & 0,5 & 6,6 & 32,5 & 369 & 617 \\
\hline 4 & 70 & 0,5 & 6,3 & 27,8 & 371 & 621 \\
\hline 5 & 80 & 0,7 & 6,9 & 24,9 & 374 & 620 \\
\hline 6 & 80 & 0,3 & 6,9 & 26,3 & 375 & 620 \\
\hline 7 & 70 & 0,22 & 6,4 & 29,2 & 372 & 620 \\
\hline 8 & 60 & 0,3 & 5,9 & 27,4 & 361 & 617 \\
\hline 9 & 60 & 0,7 & 5,8 & 29,8 & 362 & 618 \\
\hline 10 & 70 & 0,3 & 6,4 & 28,1 & 372 & 620 \\
\hline
\end{tabular}

Note. A and $\mathrm{B}$ denote the content of the factors $q_{1}$ and $q_{2}$ (Fig. 1).

To determine the significance of the factors, we used Pareto maps (Fig. 1, a-d) and graphs of normal probabilistic distribution (Fig. 1, e-h).

It is shown on Pareto maps (Fig. 1, a-d) that those factors and their combinations (columns corresponding to them on Pareto maps) that cross the vertical line with $95 \%$ confidence probability have statistically significant effects.

Also, the analysis of the obtained graphs of diagnostic of prediction values errors (Fig. 1, e-h) shows that the factors and their combinations, which are substantially deviating from the straight of normal distribution, are significant in the mathematical model, in contrast to other factors located directly at the distribution straight line. These results confirm the conclusions of the significance of the factors of mathematical model, which were made using the Pareto map (Fig. 1, a-d).

Excluding insignificant factors and their combinations, we received surfaces of responses for physicomechanical $\left(E, \sigma_{b}\right)$ and thermophysical $\left(T, T_{0}\right)$ properties of PCM (Fig. 2, a-d), as well as contour graphs (Fig. 2, e-h).

Mathematical models of physic-mechanical $\left(E, \sigma_{b}, W\right)$ and thermophysical $\left(T, T_{0}\right)$ properties of PCM are given in Table 3. 
The usage of the method of mathematical ...

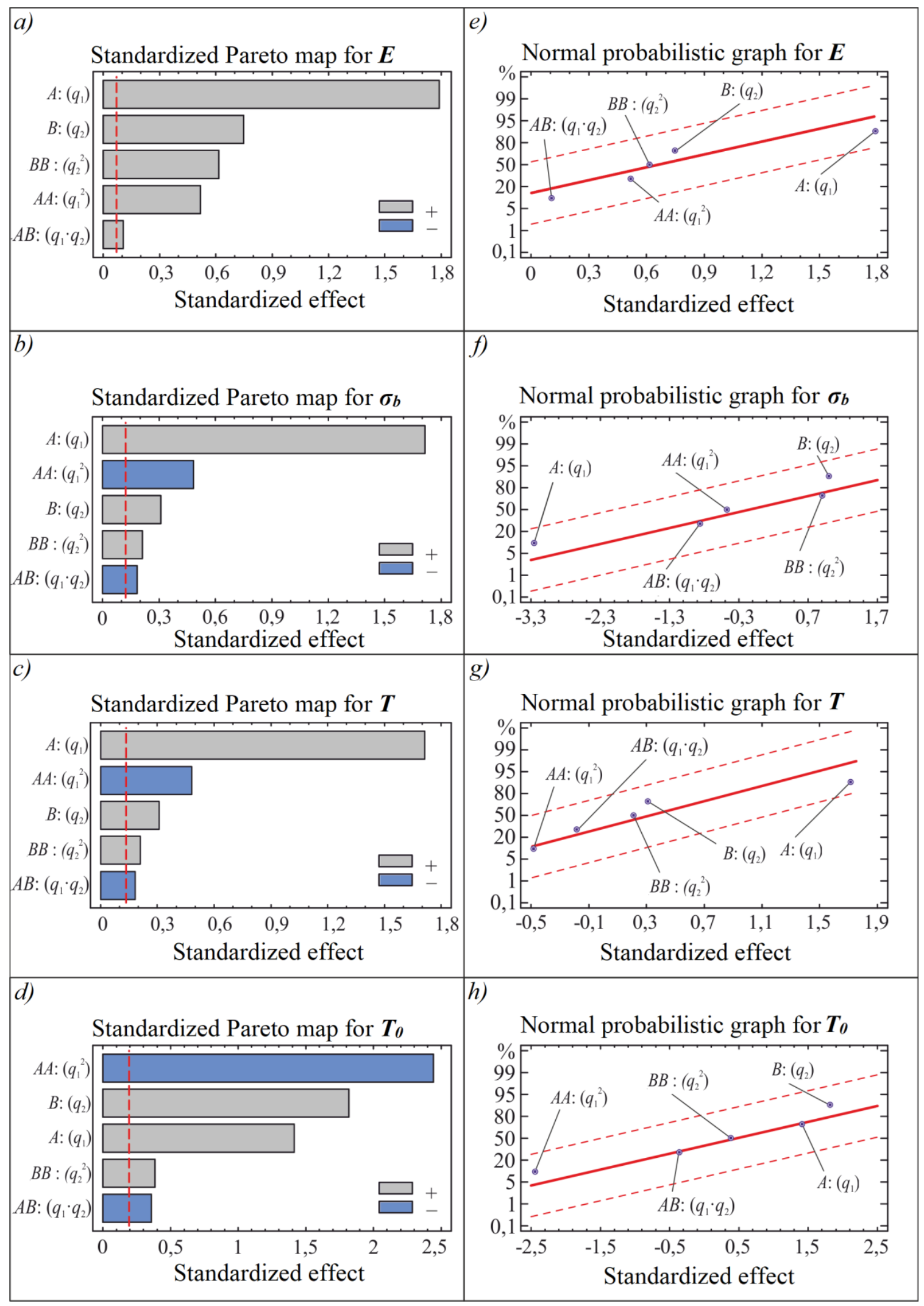

Figure 1. Pareto maps (a-d) and graphs of diagnostic of deviation of prediction values errors of the output parameter from the normal distribution (e-h) for the responses $E, \sigma_{b}, T \mathrm{i} T_{0}$ 


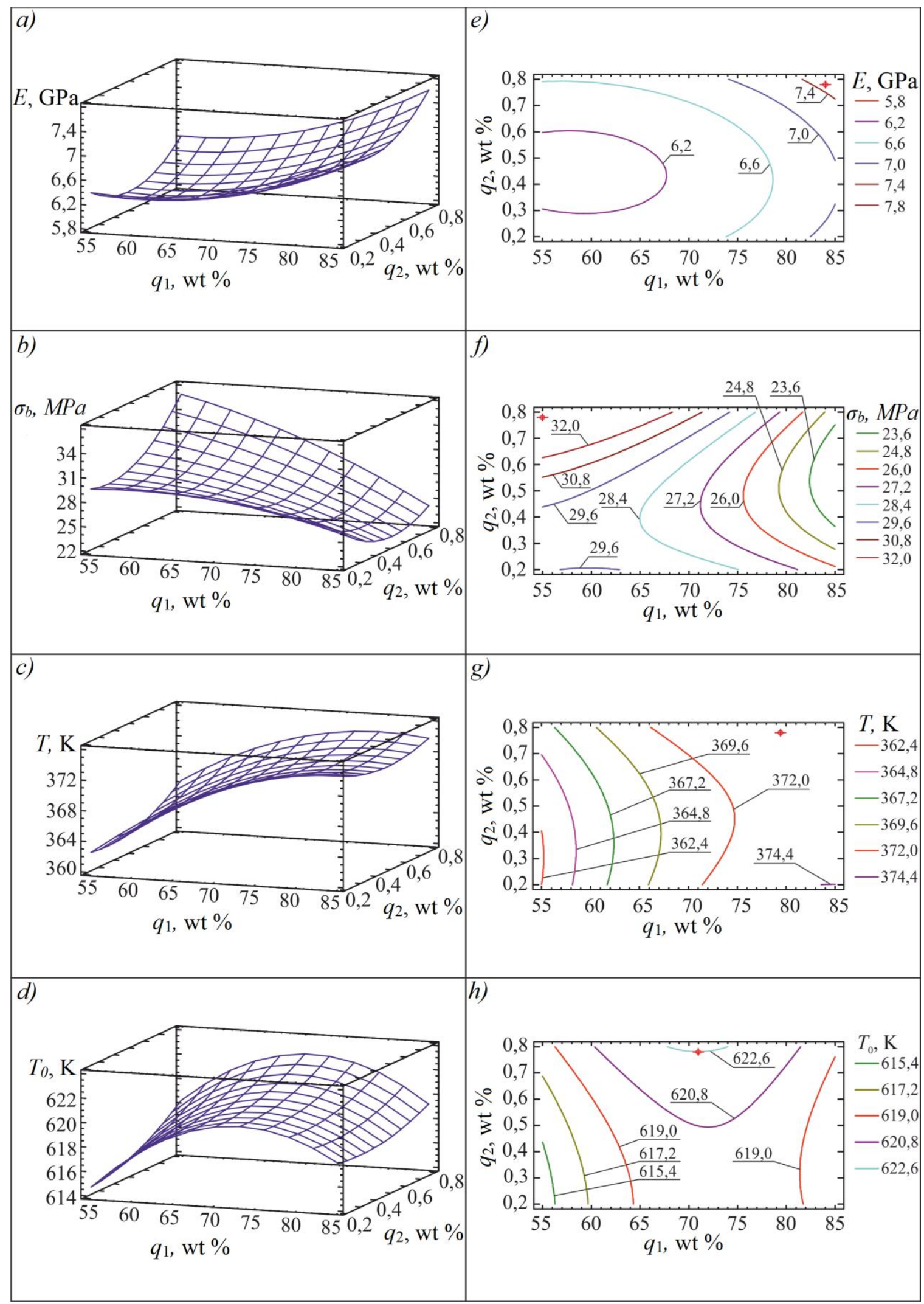

Figure 2. Response surfaces (a-d) and contour graphs (e-h) for the response $E, \sigma_{b}, T$ and $T_{0}$, shown in Table 4 
a)

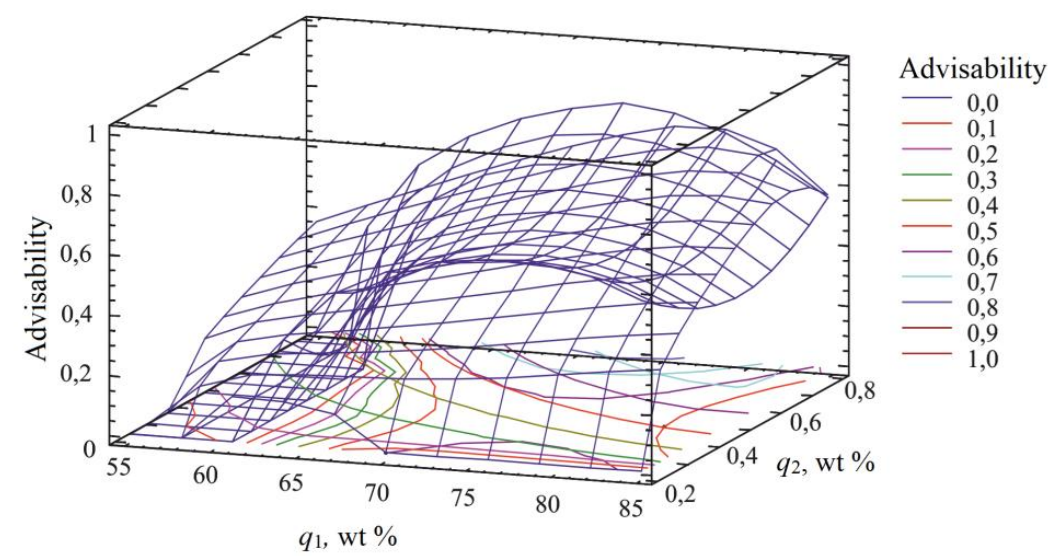

b)
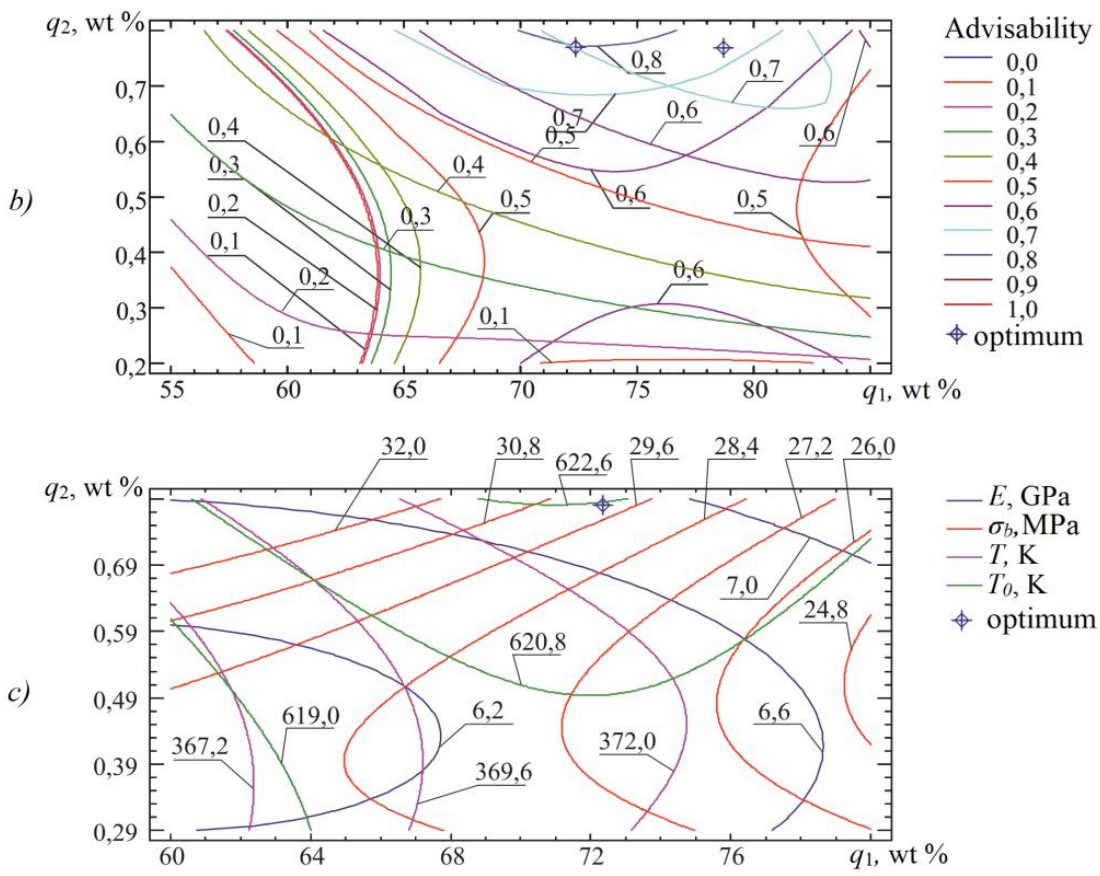

Figure 3. Surface of advisability (a), contour graph of advisability (b) and contour graphs (c) for the responses $E, \sigma_{b}, T$ and $T_{0}$

The optimum values of indicators of physicomechanical and thermophysical properties of PCM at the corresponding content of the fillers (microtalc $-q_{1}$ and silver carbonate $-q_{2}$ ) according to the data of statistical processing are given in Table 4.

Table 3

Mathematical models of physicomechanical and thermophysical properties of PCM

\begin{tabular}{|l|c|c|}
\hline \multicolumn{1}{|c|}{ Regression model } & $\begin{array}{c}\text { Determination } \\
\text { coefficient } \\
R^{2}, \%\end{array}$ & $\begin{array}{c}\text { Adjusted } \\
\text { coefficient } \\
R_{a d j}^{2} \%\end{array}$ \\
\hline$E=11,59-0,153 \cdot q_{1}-4,52 \cdot q_{2}+0,00126 \cdot q_{1}^{2}+0,0125 \cdot q_{1} \cdot q_{2}+4,25 \cdot q_{2}^{2}$ & 99,8 & 89,6 \\
\hline$\sigma_{b}=7,61+0,740 \cdot q_{1}+7,78 \cdot q_{2}-0,0054 \cdot q_{1}^{2}-0,475 \cdot q_{1} \cdot q_{2}+29,22 \cdot q_{2}^{2}$ & 99,8 & 93,1 \\
\hline$T=275,7+2,346 \cdot q_{1}+3,589 \cdot q_{2}-0,0135 \cdot q_{1}^{2}-0,25 \cdot q_{1} \cdot q_{2}+16,75 \cdot q_{2}^{2}$ & 99,9 & 90,4 \\
\hline$T_{0}=525,1+2,596 \cdot q_{1}+5,219 \cdot q_{2}-0,0176 \cdot q_{1}^{2}-0,25 \cdot q_{1} \cdot q_{2}+7,83 \cdot q_{2}^{2}$ & 99,9 & 96,1 \\
\hline
\end{tabular}


After obtaining polynomial regression equations (Table 3), connecting dependent and independent variables, the mathematical model was optimized with the simultaneous consideration of all response - indicators of physicomechanical and thermophysical properties of PCM for the purpose to determine the optimum content of fillers. The function of advisability (preferred use) was evaluated throughout the range of this model. The results of optimization are given on Figure 3 and in Table 5.

Table 4

The optimum values of indicators of physicomechanical and thermophysical properties of PCM

\begin{tabular}{|c|c|c|c|}
\hline \multicolumn{2}{|c|}{ Optimum values } & \multicolumn{2}{c|}{ Content of fillers } \\
\cline { 3 - 4 } \multicolumn{2}{|c|}{} & $q_{1}$, wt $\%$ & $q_{2}$, wt $\%$ \\
\hline$E_{o p t}, \mathrm{GPa}$ & 7,49 & 84 & 0,78 \\
\hline$\sigma_{b \text { opt }}, \mathrm{MPa}$ & 35,5 & 55 & 0,78 \\
\hline$T_{\text {opt }}, \mathrm{K}$ & 374,1 & 79,4 & 0,78 \\
\hline$T_{0 \text { opt }}, \mathrm{K}$ & 622,6 & 70,9 & 0,78 \\
\hline
\end{tabular}

Note. $q_{1}$ - the content of microtalc in PCM; $q_{2}$ - the content of silver carbonate in PCM.

When optimizing the combination of experimental factors was determined for all given responses by maximizing each of them.

The maximum value of the generalized advisability of $D_{\text {opt }}=0,798$ (corresponding to the permissible and good quality level on the scale of advisability) was obtained as a result of the optimization performed for PCM, at which the content of fillers in PCM is:

$q_{1}=72,3$ wt $\%$ - the content of microtalc;

$q_{2}=0,78$ wt $\%$ - the content of silver carbonate.

The values of responses for the specified content of the fillers in the PCM are:

$E=7,19 \mathrm{GPa}$ - modulus of elasticity under bending;

$\sigma_{b}=34,1 \mathrm{MPa}$ - destructive bending stresses;

$T=373,7 \mathrm{~K}$ - heat resistance (by Martens);

$T_{0}=623 \mathrm{~K}$ - temperature of the start of the destruction process.

Comparing the values obtained as a result of optimization, with the values given in Table 4, it can be argued that the relative error will be: for modulus of elasticity under bending - 4,0\%; for destructive bending stresses - 3,9\%; for heat resistance (by Martens) - 0,2\%; for temperature of the start of the destruction process $-0,1 \%$. This allows us to confirm about the adequacy of the received data and their consistency with the results of optimization by the criterion of advisability.

Table 5

\section{Optimization results for PCM}

\begin{tabular}{|c|c|c|c|c|c|c|c|c|c|}
\hline \multirow{4}{*}{ № } & \multicolumn{4}{|c|}{$\begin{array}{l}\text { Simultaneous combination of responses } \\
\text { to determine advisability }\end{array}$} & \multicolumn{4}{|c|}{$\begin{array}{l}\text { Partial advisability for the appropriate } \\
\text { optimization parameter }\end{array}$} & $\begin{array}{l}\text { Generalized } \\
\text { advisability }\end{array}$ \\
\hline & \multicolumn{4}{|c|}{$Y_{j}$} & \multicolumn{4}{|c|}{$d_{i}$} & $D=\sqrt[n]{\prod_{i=1}^{n} d_{i}}$ \\
\hline & $E$ & $\sigma_{b}$ & $T$ & $T_{0}$ & $d_{1}(E)$ & $d_{2}\left(\sigma_{b}\right)$ & $d_{3}(T)$ & $d_{4}\left(T_{0}\right)$ & - \\
\hline & GPa & $\mathrm{MPa}$ & $\mathrm{K}$ & $\mathrm{K}$ & - & - & - & - & $\begin{array}{lll}- & \\
-\end{array}$ \\
\hline 1 & 0,692 & 0,692 & 0,692 & 0,692 & 0,798 & 0,692 & 0,692 & 0,692 & 0,798 \\
\hline 2 & 0,521 & 0,066 & 0,441 & 0,130 & 0,385 & 0,521 & 0,066 & 0,441 & 0,385 \\
\hline 3 & 0,420 & 0,677 & 0,392 & 0,066 & 0,472 & 0,420 & 0,677 & 0,392 & 0,472 \\
\hline 4 & 0,264 & 0,375 & 0,488 & 0,420 & 0,551 & 0,264 & 0,375 & 0,488 & 0,551 \\
\hline 5 & 0,569 & 0,177 & 0,619 & 0,316 & 0,548 & 0,569 & 0,177 & 0,619 & 0,548 \\
\hline 6 & 0,569 & 0,268 & 0,657 & 0,316 & 0,589 & 0,569 & 0,268 & 0,657 & 0,589 \\
\hline 7 & 0,316 & 0,475 & 0,534 & 0,316 & 0,570 & 0,316 & 0,475 & 0,534 & 0,570 \\
\hline 8 & 0,095 & 0,346 & 0,066 & 0,066 & 0,258 & 0,095 & 0,346 & 0,066 & 0,258 \\
\hline 9 & 0,066 & 0,516 & 0,093 & 0,130 & 0,303 & 0,066 & 0,516 & 0,093 & 0,303 \\
\hline 10 & 0,316 & 0,397 & 0,534 & 0,316 & 0,554 & 0,316 & 0,397 & 0,534 & 0,554 \\
\hline
\end{tabular}


The usage of the method of mathematical ...

\section{Conclusions}

The mathematical models of physicomechanical and thermophysical characteristics of composites were obtained by the method of statistical processing of the results of the study materials. As a result of optimization the property metrics for the material with particles of microtalc $(q=70 \ldots 80$ wt $\%)$ and silver carbonate $(q=0,7 \ldots 1,0$ wt $\%)$ are: modulus of elasticity under bending $-E=7,2 \mathrm{GPa}$; destructive bending stresses $-\sigma_{b}=34,1 \mathrm{MPa}$; heat resistance $-T=373,7 \mathrm{~K}$; temperature of the start of the destruction process $T_{0}=623 \mathrm{~K}$.

\section{References}

1 Kal'ba E.M. Adhesion strength of polymer-containing protective coatings / E.M. Kal'ba, A.V. Buketov, P.P. Savchuk, S.M. Holotenko // Materials Science. - 1999. - 35(1). - P. 125-128.

2 Savchuk P.P. Structure and functional properties of epoxy composites reinforced with superfine particles / P.P. Savchuk, A.G. Kostornov // Powder Metallurgy and Metal Ceramics. — 2009. — 48(9-10). P. 555-559.

3 Savchuk P.P. Rheological properties of epoxy composites with different reinforcement contents / P.P. Savchuk, A.G. Kostornov // Powder Metallurgy and Metal Ceramics. — 2009. — 48(3-4). — P. 157-161.

4 Savchuk P.P. Friction wear of modified epoxy composites / P.P. Savchuk, A.G. Kostornov, V.P. Kashitskii, O.L. Sadova // Powder Metallurgy and Metal Ceramics. - 2014. - 53(3-4). - P. 205-209.

5 Savchuk P.P. Friction wear of modified epoxy composites / P.P. Savchuk, V.P. Kashitskii, O.L. Sadova, O.M. Lyushuk // Powder Metallurgy and Metal Ceramics. - 2017. - 56(7-8). - P. 448-455.

6 Yanovsky Yu.G. Special features of the structure of carbon nanotubes in polymer composite media/ Yu.G. Yanovsky, G.V. Kozlov, Z.B. Zhirikova, V.Z. Aloev, Yu.N. Karnet // Nanomechanics Science and Technology: An International Journal. - 2012. - 3(2). - P. 99-124.

7 Aygubova A. Effective length of a nanofiller and the degree of reinforcement of polymer/carbon nanotubes (nanofibers) nanocomposites / A. Aygubova, Y. Karnet, G. Kozlov, G. Magomedov // Nanomechanics Science and Technology: An International Journal. - 2016. - 7(4). - P. 349-354.

8 Burya A.I. Temperature and density determination for heat flux in the area of the shaft-bushing contact / A.I. Burya, B. Peleshenko, I. Rula // Journal of Friction and Wear. - 2010. - 31(6). - P. 443-448.

9 Dolbin I.V. The structure and thermal stability of polymer materials: A fractal model / I.V. Dolbin, A.I. Burya, G.V. Kozlov // High Temperature - 2007. - 45(3). - P. 313-316.

10 Burya A.I. Friction and wear of organoplastics based on aromatic polyamide of phenylone type / A.I. Burya, O.A. Naberezhnaya // Journal of Friction and Wear. - 2016. - 37(3). - P. 259-262.

11 Kozlov G.V. Interactions between polymers and carbon nanotubes and their impact on the properties of nanocomposites / G.V. Kozlov, I.V. Dolbin, Yu.N. Karnet, A.N. Vlasov // Composites: Mechanics, Computations, Applications: An International Journal. - 2018. - 9(3). - P. 239-246.

12 Kozlov G.V. Mechanism of growth of interfacial regions in polymer / carbon nanotube nanocomposites / G.V. Kozlov, A.N. Vlasov, I.V. Dolbin, Yu.N. Karnet // Composites: Mechanics, Computations, Applications: An International Journal. - 2019. - 10(3). - P. 213-220.

13 Kozlov G.V. The effect of nanofiller structure on the reinforcement degree of polymer/carbon nanotubes nanocomposites / G.V. Kozlov, I.V. Dolbin, Yu.N. Karnet // Nanoscience and Technology: An International Journal. - 2017. - 8(2). - P. 123-131.

14 Valiev H.H. Application of quantum-chemical modeling results in experimental investigations of silicone composites / H.H. Valiev, V.V. Vorobyev, Yu.N. Karnet, Yu.V. Kornev, O.B. Yumaschev // Materials Physics and Mechanics. - 2017. - 32. - P. 293-297.

15 Kozlov G.V. The effective length of a nanofiller and reinforcement degree of polymer/carbon nanotubes (nanofilaments) nanocomposites / G.V. Kozlov, A.Ch. Aygubova, G.M. Magomedov, Yu.N. Karnet // Nanoscience and Technology: An International Journal. - 2015. - 6(3). - P. 203-208.

16 Yudin V.E. Effect of the nanoparticles with various structures and morphologies on the thermo-mechanical properties of epoxy-based carbon fiber-reinforced plastics / V.E. Yudin, E.S. Molchanov, K. Kydralieva, E.M. Ivankova, V.Yu. Elokhovsky, G.V. Vaganov // Nanoscience and Technology: An International Journal. - 2013. - 4(1). - P. 47-58. 
17 Valiev H.H. Atomic force microscopy and physical - mechanical properties of new elastomer composites / H.H. Valiev, Yu.N. Karnet, N.L. Kochurov, M.S. Parshina, N.A. Semenov, O.B. Yumaschev, Yu.G. Yanovsky // Materials Physics and Mechanics. - 2016. - 26. - P. 45-48.

18 Mikitaev A.K. Fractal models of the reinforcement of polymer particulate-filled nanostructured composites by nanoparticle aggregates / A.K. Mikitaev, Yu.G. Yanovsky, G.V. Kozlov, Yu.N. Karnet // Nanoscience and Technology: An International Journal. - 2013. - 4(1). - P. 47-58.

19 Kornev Yu.V. Physical model of the behavior of polymer nanostructured composites in nanoindentation / Yu.V. Kornev, O.V. Boiko, G.V. Kozlov, Yu.G. Yanovsky, Yu.N. Karnet // Nanoscience and Technology: An International Journal. - 2010. - 1(4). - P. 291-300.

20 Sapronov O.O. Features of structural processes in epoxy composites filled with silver carbonate on increase in temperature / O.O. Sapronov, A.V. Buketov, D.O. Zinchenko, V.M. Yatsyuk // Composites: Mechanics, Computations, Applications. An International Journal. - 2017. - № 8(1). - P. 47-66.

21 Букетов А.В. K вопросу оптимизации ингредиентов композитных материалов на основе эпоксидиановой смолы / А.В. Букетов, А.В. Шарко, Д.А. Зинченко, Д.М. Степанчиков // Вестн. Караганд. ун-та. Сер. Математика. - 2017. - 2(86). - С. 37-44.

22 Buketov A.V. Investigation of the hydroabrasive wear of epoxy composites with two-component filler / A.V. Buketov, O.O. Sapronov, M.V. Brailo, D.O. Zinchenko, V.D. Nihalatii // Materials Science. - 2017. - 53(1). - P. 62-66.

23 Букетов А.В. Исследование физико-механических свойств композитных материалов на основе эпоксидиановой смолы, отвержденной полиэтиленполиамином, с добавлением пластификатора-антипирена трихлорэтилфосфата / А.В. Букетов, А.В. Акимов, Д.А. Зинченко // Вестн. Хмельницкого нац. ун-та. Технические науки. - 2015. - № 5. - С. 126-133.

24 Букетов А.В.Влияние микродисперсного карбоната серебра на свойства эпоксикомпозитов / А.В. Букетов, А.А. Сапронов, Д.А. Зинченко, В.Н. Яцюк // Механика композиционных материалов и конструкций. - 2015. - С. 534-548.

25 Букетов А.В. Дослідження впливу мікродисперсних антифрикційних наповнювачів на адгезійну міцність епоксикомпозитів / А.В. Букетов, Д.О. Зінченко, В.Д. Нігалатій // Наукові нотатки: Міжвузівський збірник - Луцькю, 2016. - № 53. - С. 17-23.

26 Buketov A.V. Nanomodified dispersed particles- and synthetic fibers-filled epoxy composite materials for the metal-polymer tribosystems of transport vehicles / A.V. Buketov, D.O. Zinchenko, S.O. Smetankin // Nanomechanics Science and Technology: An International Journal. — 2017. - 8(1). — P. 41-54.

27 Букетов А.В. Вплив синтетичних дискретних волокон на властивості епоксидних композитів для захисних покриттів / А.В. Букетов, Д.О. Зінченко, О.В. Шарко // Журнал нано- та електронної фізики. Суми. - 2017. - Т. 9. - № 2. - С. 02014-1-02014-5.

28 Zinchenko D.O. Nanomodified epoxycomposite materials for metal-polymeric tribosystems of transport vehicles / D.O. Zinchenko, S.O. Smetankin // Nanoscience and Technology: An International Journal. 2018. - 9(1). - P. 9-17.

29 Buketov A.V. Enhancing performance characteristics of equipment of sea and river transport by using epoxy composites / A.V. Buketov, P.O. Maruschak, O.O. Sapronov, D.O. Zinchenko, V.M. Yatsyuk, S. Panin // TRANSPORT. - Vilnius Gediminas Technical University (VGTU), 2016. - Vol. 31(3). P. 333-342.

30 Букетов А.В. Исследование влияния нанодисперсного оксида серебра на структуру и теплофизические свойства полимерных композитных материалов / А.В. Букетов, А.А. Сапронов, Д.А. Зинченко, В.Н. Яцюк // Пластические массы. - 2017. - № 5, 6. - С. 28-37. 
Д.А. Зинченко, А.В. Акимов, М.В. Бабий

\title{
Математикалық статистика әдісімен композиттік материалдар құрамын оңтайландыру
}

\begin{abstract}
Мақалада математикалық статистика әдістерімен қорғаныс жабындарының адгезиялық және функционалдық қабаттарын қалыптастыру үшін полимерлік материалдар толтырғыштары микротальктің (дисперсиялығы $\mathrm{d}=7 \ldots 10 \mu \mathrm{m}$ ) және күміс карбонатының (дисперсиялығы $\mathrm{d}=0,5 \mu \mathrm{m}$ ) тиімді құрамы анықталған. Материалдарды зерттеу нәтижелерін статистикалық өңдеу әдістері арқылы композиттердің физика-механикалық және жылуфизикалық сипаттамаларының математикалық моделі алынды.
\end{abstract}

Kiлm сөздер: композит, математикалық статистика, серпімділік модулі, деструкция, оңтайландыру.

\author{
Д.А. Зинченко, А.В. Акимов, М.В. Бабий
}

\section{Оптимизация состава композитных материалов методом математической статистики}

\begin{abstract}
В статье методом математической статистики определено оптимальное содержание в полимерных материалах наполнителей микроталька (дисперсностью $\mathrm{d}=7 \ldots 10$ мкм) и карбоната серебра (дисперсностью $\mathrm{d}=0,5$ мкм) для формирования адгезионного и функционального слоев защитных покрытий. Методом статистической обработки результатов исследования материалов получены математические модели физико-механических и теплофизических характеристик композитов.
\end{abstract}

Ключевые слова: композит, математическая статистика, модуль упругости, деструкция, оптимизация.

\section{References}

1 Kal'ba E.M., Buketov A.V., Savchuk P.P., \& Holotenko S.M. (1999). Adhesion strength of polymercontaining protective coatings. Materials Science, 35, 1, 125-128.

2 Savchuk P.P., \& Kostornov A.G. (2009). Structure and functional properties of epoxy composites reinforced with superfine particles. Powder Metallurgy and Metal Ceramics, 48, 9-10, 555-559.

3 Savchuk P.P., \& Kostornov A.G. (2009). Rheological properties of epoxy composites with different reinforcement contents. Powder Metallurgy and Metal Ceramics, 48, 3-4, 157-161.

4 Savchuk P.P., Kostornov A.G., Kashitskii V.P., \& Sadova O.L. (2014). Friction wear of modified epoxy composites, Powder Metallurgy and Metal Ceramics, 53, 3-4, 205-209.

5 Savchuk P.P., Kashitskii V.P., Sadova O.L., \& Lyushuk O.M. (2017). Friction wear of modified epoxy composites. Powder Metallurgy and Metal Ceramics, 56, 7-8, 448-455.

6 Yanovsky Yu.G., Kozlov G.V., Zhirikova Z.B., Aloev V.Z., \& Karnet Yu.N. (2012). Special features of the structure of carbon nanotubes in polymer composite media. Nanomechanics Science and Technology: An International Journal, 3, 2, 99-124.

7 Aygubova A., Karnet Y., Kozlov G., \& Magomedov G. (2016). Effective length of a nanofiller and the degree of reinforcement of polymer/carbon nanotubes (nanofibers) nanocomposites. Nanomechanics Science and Technology: An International Journal, 7, 4, 349-354.

8 Burya A., Peleshenko B., \& Rula I. (2010). Temperature and density determination for heat flux in the area of the shaft-bushing contact. Journal of Friction and Wear, 31, 6, 443-448.

9 Dolbin I.V., Burya A.I., \& Kozlov G.V. (2017). The structure and thermal stability of polymer materials: A fractal model. High Temperature, 45, 3, 313-316.

10 Burya A.I., \& Naberezhnaya O.A. (2016). Friction and wear of organoplastics based on aromatic polyamide of phenylone type. Journal of Friction and Wear, 37, 3, 259-262. 
11 Kozlov G.V., Dolbin I.V., Karnet Yu.N., \& Vlasov A.N. (2018). Interactions between polymers and carbon nanotubes and their impact on the properties of nanocomposites. Composites: Mechanics, Computations, Applications: An International Journal, 9, 3, 239-246.

12 Kozlov G.V., Vlasov A.N., Dolbin I.V., \& Karnet Yu.N. (2019). Mechanism of growth of interfacial regions in polymer / carbon nanotube nanocomposites. Composites: Mechanics, Computations, Applications: An International Journal, 10, 3, 213-220.

13 Kozlov G.V., Dolbin I.V., \& Karnet Yu.N. (2017). The effect of nanofiller structure on the reinforcement degree of polymer/carbon nanotubes nanocomposites. Nanoscience and Technology: An International Journal, 8, 2, 123-131.

14 Valiev H.H., Vorobyev V.V., Karnet Yu.N., Kornev Yu.V., \& Yumaschev O.B. (2017). Application of quantum-chemical modeling results in experimental investigations of silicone composites. Materials Physics and Mechanics, 32, 293-297.

15 Kozlov G.V., Aygubova A.Ch., Magomedov G.M., \& Karnet Yu.N. (2015). The effective length of a nanofiller and reinforcement degree of polymer/carbon nanotubes (nanofilaments) nanocomposites. Nanoscience and Technology: An International Journal, 6, 3, 203-208.

16 Yudin V.E., Molchanov E.S., Kydralieva K., Ivankova E.M., Elokhovsky V.Yu., \& Vaganov G.V. (2013). Effect of the nanoparticles with various structures and morphologies on the thermo-mechanical properties of epoxy-based carbon fiber-reinforced plastics. Nanoscience and Technology: An International Journal, 4, 1, 47-58.

17 Valiev H.H., Karnet Yu.N., Kochurov N.L., Parshina M.S., Semenov N.A., Yumaschev O.B., \& Yanovsky Yu.G. (2016). Atomic force microscopy and physical-mechanical properties of new elastomer composites. Materials Physics and Mechanics, 26, 45-48.

18 Mikitaev A.K., Yanovsky Yu.G., Kozlov G.V., \& Karnet Yu.N. (2013). Fractal models of the reinforcement of polymer particulate-filled nanostructured composites by nanoparticle aggregates. Nanoscience and Technology: An International Journal, 4, 1, 47-58.

19 Kornev Yu.V., Boiko O.V., Kozlov G.V., Yanovsky Yu.G., \& Karnet Yu.N. (2010). Physical model of the behavior of polymer nanostructured composites in nanoindentation. Nanoscience and Technology: An International Journal, 1, 4, 291-300.

20 Sapronov O.O., Buketov A.V., Zinchenko D.A., \& Yatsyuk V.M. (2017). Features of structural processes in epoxy composites filled with silver carbonate on increase in temperature. Composites: Mechanics, Computations, Applications. An International Journal, 8,1, 47-66.

21 Buketov, A.V., Sharko, A.V., Zinchenko, D.A., \& Stepanchikov, D.M. (2017). K voprosu optimizatsii inhredientov kompozitnykh materialov na osnove epoksidianovoi smoly [On the issue of optimization of ingredients of composite materials based on epoxy resin]. Vestnik Karahandinskoho universiteta. Seriia Matematika - Bulletin of the Karaganda University. Mathematics series, 2, 86, 37-44 [in Russian].

22 Buketov A.V., Sapronov O.O., Brailo M.V., Zinchenko D.O., \& Nihalatii V.D. (2017). Investigation of the hydroabrasive wear of epoxy composites with two-component filler. Materials Science, 53, 1, 62-66.

23 Buketov, A.V., Akimov, A.V., \& Zinchenko, D.A. (2015). Issledovanie fiziko-mekhanicheskikh svoistv kompozitnykh materialov na osnove epoksidianovoi smoly, otverzhdennoi polietilenpoliaminom, s dobavleniem plastifikatora-antipirena trikhloretilfosfata [Investigation of physical and mechanical properties of composite materials based on epoxy resin, cured with polyethylene polyamine, with the addition of plasticizerflame retardant trichloroethyl phosphate] Vestnik Khmelnitskoho natsionalnoho universiteta. Tekhnicheskie nauki - Bulletin of Khmelnitsky National University. Technical science. - Khmelnitsky: KhNU, No. 5, 126-133 [in Russian].

24 Buketov, A.V., Sapronov, A.A., Zinchenko, D.A., \& Iatsiuk, V.N. (2015). Vliianie mikrodispersnoho karbonata serebra na svoistva epoksikompozitov. [Effect of microdispersed silver carbonate on the properties of epoxy composites]. Mekhanika kompozitsionnykh materialov i konstruktsii. - Mechanics of composite materials and structures, 4, 534-548 [in Russian].

25 Buketov, A.V., Zinchenko, D.O., \& Nigalatii, V.D. (2016). Doslidzhennia vplivu mikrodispersnikh antifriktsiinikh napovniuvachiv na adgeziinu mitsnist epoksikompozitiv [Investigation of the effect of microdisperse antifriction fillers on the adhesive strength of epoxy composites]. Mizhvuzivskii zbirnik «Naukovi notatki». Lutsk - Interuniversity collection «Research notes». Lutsk, 53, 17-23 [in Ukrainian]. 
26 Buketov, A.V., Zinchenko, D.O., \& Smetankin, S.O. (2017). Nanomodified dispersed particles- and synthetic fibers-filled epoxy composite materials for the metal- polymer tribosystems of transport vehicles. Nanomechanics Science and Technology: An International Journal, 8, 1, 41-54.

27 Buketov, A.V., Zinchenko, D.O., \& Sharko, O.V. (2017). Vpliv sintetichnikh diskretnikh volokon na vlastivosti epoksidnikh kompozitiv dlia zakhisnikh pokrittiv. [Influence of synthetic discrete fibers on the properties of epoxy composites for protective coatings]. Zhurnal nano- ta elektronnö fiziki. Journal of nano-and electronic physics. Sumy-2017, Vol. 9, No. 2, 02014-1 - 02014-5 [in Ukrainian].

28 Zinchenko, D.O., \& Smetankin, S.O. (2018). Nanomodified epoxycomposite materials for metal-polymeric tribosystems of transport vehicles. Nanoscience and Technology: An International Journal, 9, 1, 9-17.

29 Buketov, A.V., Maruschak, P.O., Sapronov, O.O., Zinchenko, D.O., Yatsyuk, V.M., \& Panin, S. (2016). Enhancing performance characteristics of equipment of sea and river transport by using epoxy composites. TRANSPORT. Vilnius Gediminas Technical University (VGTU), 31, 3, 333-342.

30 Buketov, A.V., Sapronov, A.A., Zinchenko, D.A., Iatsiuk, V.N. (2017). Issledovanie vliianiia nanodispersnoho oksida serebra na strukturu i teplofizicheskie svoistva polimernykh kompozitnykh materialov [Investigation of the effect of nanodispersed silver oxide on the structure and thermophysical properties of polymer composite materials]. Plasticheskie massy. - Plastic masses, 5-6, 28-37 [in Russian]. 